\title{
Doctor Eduardo Liceaga, pediatrician
}

\author{
Manuel Antonio Baeza-Bacab
}

Universidad Autónoma de Yucatán, Faculty of Medicine, Yucatán, Mexico

\begin{abstract}
Although much has been written about Dr. Eduardo Liceaga's life and works, very little is mentioned about his activities in the field of children's healthcare. At the beginning of his professional activities Dr. Liceaga showed an inclination for the care of sick children. His preference for surgical matters is shown by his early works, although later he also took an interest in other childhood-related issues, and ultimately, in healthcare policies. Dr. Liceaga was the physician responsible for the first ward for sick children in Mexico at Hospital de San Andrés, first director of the Hospital de Infancia, and author of several publications on pediatric problems; he introduced the rabies vaccine in Mexico and was the founder of the Hospital General de México.
\end{abstract}

KEY WORDS: Eduardo Liceaga. Pediatrics. Hospital General de México.

\section{Introduction}

Doctor Eduardo Liceaga, the most prominent figure of Mexican medicine and a bridge between doctors Miguel F. Jiménez and Ignacio Chávez, ${ }^{1}$ was not only in charge of public health of the country, but also cultivated pediatrics, was the doctor responsible for the first children's ward in the country at San Andrés Hospital, first director of the Children's Hospital, inspirer of inaugural theses at the National School of Medicine and author of several works on diseases of children and adolescents.

Even when there are different works about Dr. Eduardo Liceaga's life and work, little has been written about his activity in the field of pediatrics, so that here we present some aspects of this facet of his professional life, which, as Dr. Gregorio Mendizábal wrote in the obituary published by Gaceta Médica de México: "may this serve as a deserved tribute to the illustrious veteran, to the hard-working champion who devoted his entire life to the service of science, of humanity and of the fatherland". ${ }^{2}$

\section{Origin and training of the distinguished Guanajuatan doctor}

He was born on October 13, 1839 in the city of Guanajuato; his parents were Dr. Francisco Liceaga and Doña Trinidad Torres. He began his medical studies under the guidance of Doctors Ladislao de la Pascua and Gabino Barreda; in all the undergraduate years he obtained the best grades and, therefore, in 1865 he was awarded the gold medal Emperor Maximilian had instituted for the student who, at any professional training program, would obtain the first place in all courses. ${ }^{3}$

Upon the death of his father in 1861, Dr. Ignacio Durán, director of the School of Medicine, became his protector: he assigned him a scholarship that allowed him to continue his studies, he appointed him sub-prefect of the School of Medicine and included him in the bosom of his family and society; every time he obtained the best grade, he rewarded him with a meal and every Sunday afternoon he took him to music teacher Tomás León's house where they listened to
Correspondence:

Manuel Antonio Baeza-Bacab

E-mail: mbaezabacab @ gmail.com
Date of reception: 23-01-2017

Date of acceptance: $29-08-2017$

DOI://dx.doi.org/10.24875/GMM.M18000162
Gac Med Mex. 2018;154:335-344

Contents available at PubMed www.gacetamedicademexico.com 
classical works. It was in those gatherings where the young student acquired his taste for music. ${ }^{3}$

In addition, Dr. Durán got from emperor Maximiliano the promise to send young Liceaga to Europe to perfect his studies once he graduated as a doctor; however, on January 14, 1866, the same day he was appointed Secretary of the Mexican Philharmonic Society, he was informed that he was no longer going to be pensioned to Europe, since the new finance minister had reduced the list of civil expenditures and suppressed the corresponding item. ${ }^{4}$

These events kept the recent graduate in Mexico, which prompted him to initiate his professional activity in the capital of the country. Was appointed professor of physics and natural history at the Lyceum the emperor had just founded in the old College of San Ildefonso; shortly after, when the Conservatory of Music was opened, he was appointed professor of acoustics and phonography. ${ }^{3}$

At the San Ildefonso College there were no textbooks and the lessons were oral. In the natural history lecture, live or dried plants were used, and for animals there were models, or specimens of those that were common were examined. However, the teaching of physics demanded a cabinet, since the existing one was so old and in such a bad shape that there was not a single complete device; it was necessary to undertake a repair task that resulted in the first physics cabinet, which would give rise to that of the National Preparatory School. Mr. Joaquín Eguía Liz, the College Director, was so pleased that proposed to Archduke Maximiliano that Dr. Liceaga were graced with the Cross of the Order of Guadalupe. In his memoirs, he points out that he accepted the distinction, but that he never showed it on his chest. ${ }^{3}$

\section{The first Mexican "pediatrist"}

In his book History of medicine in Mexico. From the time of the Indians until the present, published in 1888 , Dr. Francisco Flores wrote that "pediatrics" is the specialty that deals with healing the diseases of the first months and years of life, mentioning that, in Mexico as everywhere, it is very old, because the Aztecs looked with great care after newborn children, but that no attention had been drawn to the demand of special studies to practice it until that period, even when the November 12, 1834 Curriculum officially indicated that the teaching of "children's diseases" should be imparted in the obstetrics lectures, but the truth is that this never ocurred. ${ }^{5}$

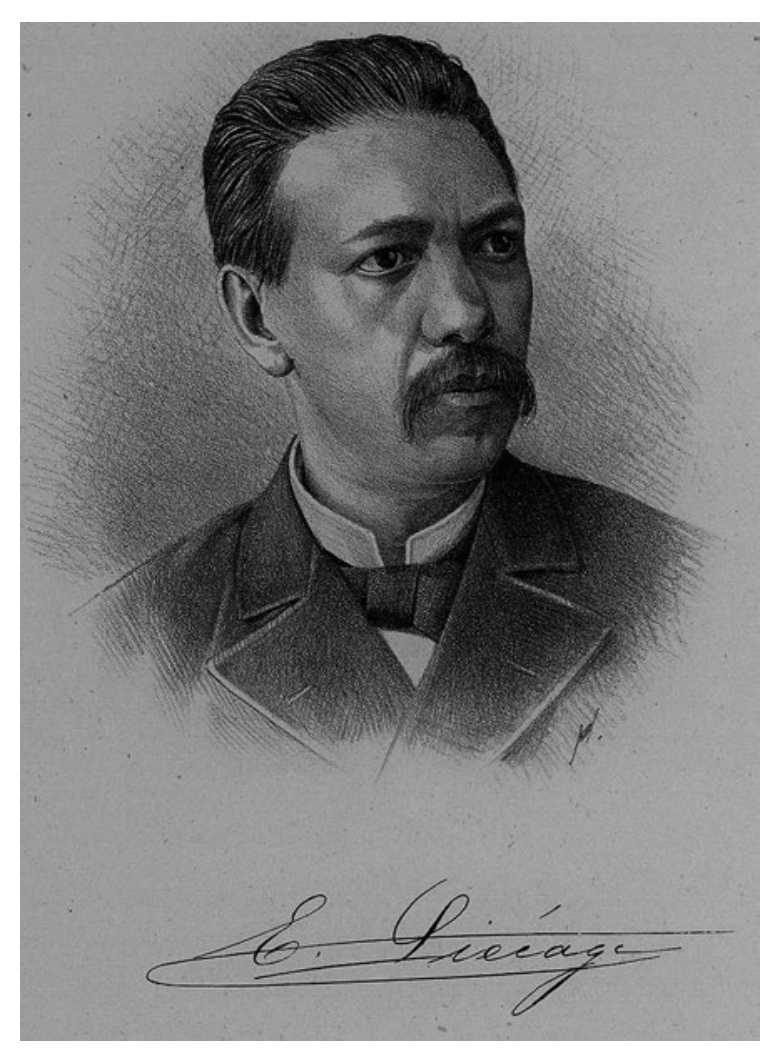

Figure 1. Doctor Eduardo Liceaga, the oldest of the Mexican "pediatrists". Image obtained from Paz I, editor. Los hombres prominentes de México. México: Imprenta y Litografía de La Patria; 1888.

In addition, Dr. Flores considered that the School of Medicine required the creation of certain courses on special clinics that would complement professional training, since it was not unusual for young doctors to ignore how to diagnose or prescribe a sick child. He claimed that although the teaching of pediatrics had not been formalized, importance was given to its practice, and that since the creation of Casa Cuna, children diseases were observed to have particularities, but it was since the establishment of a children's ward at the San Andrés Hospital and later at the Maternity and Children's Hospital when "pediatrists" began to be trained, among whom Dr. Eduardo Liceaga stood out (Figure 1). ${ }^{5}$

\section{Children's doctor at San Andrés Hospital}

Doctor Luis Fernando Gallardo, charity councilman of the Mexico City Council, promoted the creation of the first ward for the assistance of sick children at San Andrés Hospital, founded on February 7, 1868 thanks to the collaboration of Sister Juana de Antia, abbess of the Sisters of Mercy, who served at the hospital, and to the generosity of Mr. Pío Bermejillo and Mr. Nicolás de Teresa. ${ }^{4,6}$ 
The City Council opened an exam for public service in order to provide the medical post in charge of the new ward for sick children. In his memoirs, Dr. Liceaga mentions that four doctors took the exam; one of them had just arrived from Europe, where he had devoted himself to the study of children's diseases, other was a young doctor from Morelia, Dr. Valenzuela, and the other two he did not know. He relates that Dr. Manuel Carmona y Valle suggested him the idea of taking the exam, but he was afraid of measuring his strength with the other contestants, since he had graduated from school only two years prior, to which doctor Carmona replied that defeats in competitive exams are not embarrassing because they show, at least, that one has the courage to fight and that a convenient exposition provides reputation for another contest, so he signed up to take the exam. Dr. Liceaga obtained the position and, in addition, he had an assistant assigned, Mr. Abraham Díaz Gutierrez, and both made up the ward staff. ${ }^{3,5}$

The meager resources provided by the City Council to the department were not sufficient to cover its needs, which was pointed out in December 1868 in a report on hospitals prepared by Dr. Ramón F. Pacheco, member of the Higher Council of Health and councilman of the City Council Commission of Hospitals, where he noted that the ward was insufficient and did not meet the necessary hygienic conditions, to the point that some children were admitted in mats on the floor, and thus he made the commitment to find a suitable place. ${ }^{5}$

\section{Doctor and director of the Children's Hospital}

It should be noted that, in June 1865, emperor Maximiliano created a Maternity House, under the protection of Empress Carlota, in the premises occupied by the Department of Occult Births of the Poor's Hospice, located at $1^{\text {st }}$ Revillagigedo Street. Next to the Maternity, the San Carlos Shelter House was built, the purpose of which was to provide the children of working women with food and education; however, it never started operating due to the fall of the Empire in 1867.5,6

At the triumph of the Republic, Dr. Ramón F. Pacheco was appointed director of the Maternity House, who requested for the San Carlos Shelter to be ceded to the Maternity House in order to be able to expand it. Once remodeling was completed he considered the piece of land was large enough for another building and he thought of founding a children's hospital complementary to the Maternity House. ${ }^{5,6}$

Based on the report he submitted to the City Hall Commission of Hospitals, Dr. Pacheco requested the City Council the transfer of the children's ward that was found at San Andrés Hospital to the annexed as part of the Maternity House. On February 2, 1869, the City Hall approved for the sick children section to be moved to the San Carlos Shelter, which would be called Maternity and Children's Hospital thereafter. The agreement also stated that older and younger assistants would continue to perform the same duties in the new premises. One week later, Dr. Eduardo Liceaga, doctor of the children's section, was instructed to organize the department in three wards, one for boys, one for girls, and another for those who had a communicable disease..$^{5,6}$

In his memoirs, Dr. Liceaga relates that Dr. Pacheco, director of the hospital, had the intention to impose him the obligation to sleep in the establishment on order to take care of anything occurring during the night; however, Dr. Liceaga replied that he had was appointed children's doctor and that he was not in the department for the meager remuneration he received but to study the diseases of childhood. ${ }^{3}$ In 1870, the Ministry of the Interior removed Dr. Pacheco from the post of director, with Dr. Liceaga being left as the director of the entire establishment and Dr. Aniceto Ortega as director of the maternity from that moment on.5,6

When the service of the Children's Hospital was organized, Dr. Liceaga understood that it was insufficient for such a numerous a population as that of Mexico and expanded it, creating a free consultation area for poor children, whichever their illness. The rapid population increase drove doctor Liceaga to request for support to his friends doctors Francisco Chacón, Nicolás San Juan, Ramón Icaza and Manuel Barreiro, as well as to the assistants who had served before: Jesús E. Monjarás, Pedro Noriega, Francisco Hurtado, José Buiza, Lamberto Anaya, Miguel Márquez and Rafael Souza. Soon, it became necessary for consultation to be broadened to patients with surgical ailments, regardless of their age and gender. ${ }^{3}$ The premises were insufficient due to the numerous surgeries, in addition to that the room did not receive light overhead, and an operation amphitheater and annexed departments were therefore required. With the support of Congressman General Porfirio Díaz, approvalby the Congress of an amount of $\$ 10,000.00$ was achieved in order for the works to be carried out; however, the money did not arrive to the hospital and Dr. Liceaga 
had to resort again to his friends to carry out the remodeling, which included the acquisition of iron cots with oil-painted grilles in white color, soft mattresses, new bed linen and white muslin pavilions. ${ }^{3}$

A monumental semicircular amphitheater was built for the operating room with materials donated by General Vicente Riva Palacio; a skylight that allowed the entry of overhead light, given by Mrs. Catalina Barrón de Escandón, was also installed. When the work was finished, it was opened by Mr. Carlos Diez Gutiérrez, Minister of the Interior, who was kind enough to give the name "Dr. Eduardo Liceaga "to the consultation room. ${ }^{3}$

Dr. Liceaga built four small pieces of wood, isolated, oil-painted to be able to be washed whenever necessary, with the furniture and utensils that were required to provide care to children with contagious diseases, which enabled their isolation and prevented the spread of diseases. ${ }^{3}$

When Dr. Robert Koch announced the world that he had discovered a remedy that could cure tuberculosis at the $10^{\text {th }}$ International Congress of Medicine, held in Berlin in 1890, Dr. Liceaga was among the attendees, and decided to carry out an experimental investigation on the effects of tuberculin in children admitted to the Children's Hospital; since it only had 20 beds, he included also some patients who attended the consultation room of the hospital. He organized a work team with support of his colleagues who collaborated in the consultation area, assistants of the hospital and some teachers of the School of Medicine., ${ }^{3,7}$

According to the above, a bacteriology and microscopy laboratory was installed in the Children's Hospital to make there the lymph dilutions and bring it, if necessary, to other hospitals, so that it would be prepared by a single person with the knowledge and skills for such operations; Dr. Ángel Gaviño, a bacteriology professor, was asked to be in charge of the dilutions and personally perform the inoculations. Dr. Francisco Hurtado was responsible for the microscopic studies of the sputum of children with pulmonary tuberculosis, as well as coxalgia pus and blood tests. Doctor Manuel Carmona y Valle, internal clinic teacher, took care of the diagnosis of patients with pulmonary tuberculosis and of their observation during the course of tuberculin application; Dr. Rafael Lavista, a surgical clinic teacher, diagnosed and followed the evolution of patients with surgical tuberculosis for the time application of the medication lasted; Dr. Francisco Chacón was in charge of the study and surveillance of the patients who received the treatment. Doctors Alfonso
Ruiz Erdozáin, Francisco Bernáldez, Aizpuru, Francisco Ortega, Vásquez, Legorreta, Eduardo Vargas, Agustín Chacón, Ramón Icaza, Juan M. Rodríguez, Tobias Núñez, Ricardo Vértiz, Agustín Reyes, Casasola, Ricardo Egea and Vicente Morales took turns to monitor the patients during the day. The assistants took the temperature, the pulse and number of breaths of the patients every two hours during day and night, making notes of all modifications. ${ }^{3,70}$

One patient with tuberculous lupus was chosen, three with slight infiltration of the pulmonary vertex, three with coxalgia, one with cervical adenitis, one with arthritis in the knee, three with frank scrofulous manifestations, one with cystic pleurisy, one with Pott disease, one with a condition of the metatarsal bones and two with leprosy in whom conventional treatments had failed. Of these patients, 11 were children being looked after at the hospital and seven were from outpatient services, who were admitted to follow the treatment. At Hospital de Jesus, Dr. Carmona inoculated one patient with scrofulosis and another with pulmonary tuberculosis. At Hospital Concepción Béistegui one patient with coxalgia was inoculated, Professor Núñez took care of a girl with right humerus osteitis and Professor Lavista of one patient with testicular tuberculosis. In total, 23 patients, 19 children and 4 adults. $^{7}$

According to Dr. Koch's recommendation, patients with advanced pulmonary tuberculosis or patients with suspected brain or meningeal granulations or renal or cardiac or thick blood vessels' lesions were not included. The study started on January 15, 1891, with $1 \mathrm{~g}$ of lymph provided by Dr. Alberto Escobar, director of the Military Hospital for Training; when the tuberculin ran out, the study was continued with that which the President of the Republic got for the study and subsequently with lymph provided by Mr. Peón, from Yucatán, and Mr. Ramírez de Arellano, of the Health Council.7,8

The observations were analyzed and commented among the participating doctors, who arrived to the following conclusions: the cases of incipient pulmonary tuberculosis had a satisfactory evolution, but in the cases of chronic pulmonary tuberculosis, more or less advanced, the results were variable, depending on the severity of the lesions and the intensity of symptoms, such as cough, dyspnea, temperature elevation, sweat abundance, weight loss, among others. Almost all cases of surgical tuberculosis improved favorably, as well as the girl with lupus, which encouraged the group to continue using tuberculin for that disease. Tuberculin was so effective in leprosy 
patients, that it has been applied to patients with leprosy with the stained and tuberculous forms ever since; no relief was found in severe forms or in those that directly depend on the nervous system. ${ }^{3,7}$

Additionally, Dr. Liceaga described in detail the procedure to administer tuberculin, in order for the rest of the doctors for apply the treatment in the referred leprosy forms; he recommended isolation of patients, frequent personal hygiene and scrupulous cleaning of dresses, simple but nutritious food and care of all complications. ${ }^{3,7}$

\section{Pediatrics theses in the tears of the Maternity and Children's Hospital}

At the Maternity and Children's Hospital, not only the care of sick children flourished, but also the care for newborns was developed, which was accompanied by inaugural theses with pediatric and neonatal topics by students of the National School of Medicine. Among them, the one by Mariano Herrera, Some considerations about pediatrics; the one by Francisco García Luna, Usefulness of incubators and their complement, the gavage; the one by Federico Martínez, Brief notes on early childhood hygiene; Alberto Limón's Advantages of umbilical cord late ligation; and the one by Roque Macouzet, Gastric lavage in children, among others. Table 1 lists the theses with pediatric subjects that were presented at the National School of Medicine between 1869 and 1905, period of existence of the Maternity and Children's Hospital., .10

Mariano Herrera's inaugural thesis, presented in 1881, deserves special mention since it constitutes a textbook; on its 200 pages it addresses the basic aspects of pediatrics. In the introduction, the author notes that two reasons drove him to take the subject as inaugural work: its relevance and the nearly complete lack of knowledge students had on the subject when leaving professional school. The thesis was so important, that Dr. Francisco Flores pointed out that by the end of the $19^{\text {th }}$ century in Mexico, there were almost no works on pediatrics, with exception of the study by Mariano Herrera, which was dedicated to the "distinguished specialist in childhood diseases Dr. Eduardo Liceaga", 11 (Figure 2).

\section{Children, the first ones to be vaccinated against rabies}

After following step by step for several weeks the technique of preventive inoculations against rabies at the Pasteur Institute of Paris, Dr. Liceaga returned to Mexico with the brain of a rabbit inoculated with rabies. After travelling for 22 days, he arrived to Mexico City on February 10, 1888, and he began to work immediately in collaboration with doctors Nicolás Ramírez de Arellano and Agustín Reyes, and veterinarian José de la Luz Gómez, initiating inoculations of rabbits at the Bacteriology Laboratory of the Higher Council of Health. ${ }^{12,13}$

As with Pasteur, the first one to receive the anti-rabies vaccine developed in Mexico by Dr. Liceaga was a boy, Isidro Delgadillo, aged 12, who was bitten on the right leg on April 20, 1888 by a dog that was assumed to be rabid. In total, he had five deep bites on the calf, and it was considered likely for the child to contract rabies. Isidro's parents found out in the newspaper that Dr. Liceaga, who was famous and important in the capital, had brought from Paris the vaccine against rabies and had been working on it for some time; on April 23, they brought their son to the Council facilities, requesting that he'd be vaccinated. ${ }^{12-14}$ The first injection was administered at 18:50 hours of that day; Dr. Agustín Reyes introduced a syringe with the sterilized broth under the skin of the right hypochondrium of the boy. This inoculation was made without having an absolute trust in the vaccine, since the seriation of marrows was not complete, because it had not been possible for a rabies-inoculated rabbit to die every day, and the missing series were therefore replaced with marrows preserved in glycerin according to an idea of Dr. Ramírez of Arellano. On April 30, a new series was started, and on May 10, the third and last one was initiated; with these inoculations, the death of the patient was avoided and the disease could be prevented. Soon after, the vaccine was administered with equal efficacy to the children Gregorio Flores and Luz García. ${ }^{12-14}$

\section{Doctor Liceaga pediatric publications in Gaceta Médica de Mexico}

In the evening event held by the National Academy of Medicine to commemorate Dr. Eduardo Liceaga's birth centenary, on October 13, 1939 Dr. Alfonso Pruneda, perpetual secretary of the National Academy of Medicine, read a biographical sketch of the honoree, where he noted that during 50 years of active academic life he published 35 works in Gaceta Médica de México, ${ }^{15}$ out of which 13 refer to pediatric issues. The first one, which most likely corresponds to what now is known as an admission work, was entitled 
Gaceta Médica de México. 2018;154

Table 1. Theses on pediatric subjects developed at the National School of Medicine from 1869 to 1905

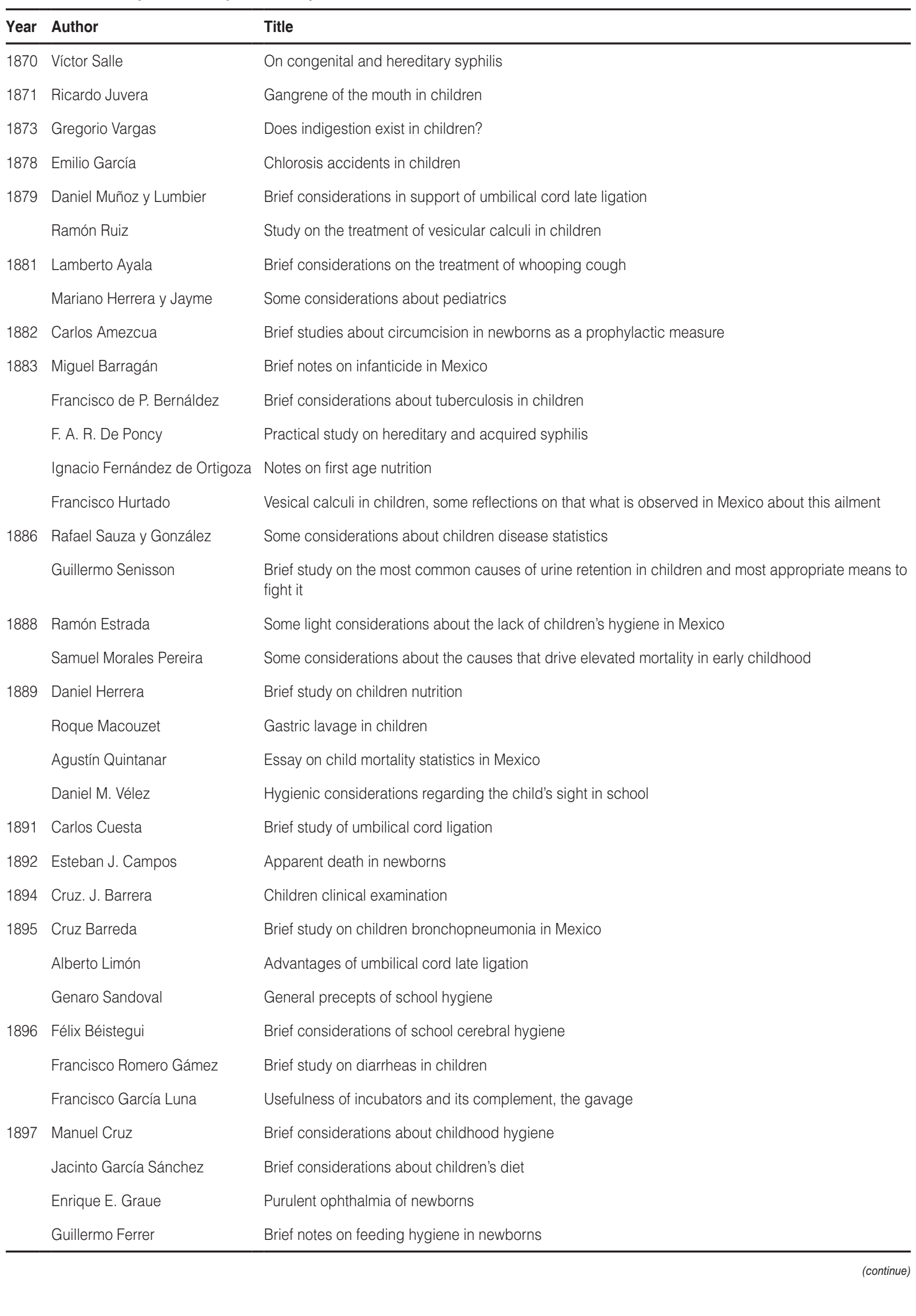


Table 1. Theses on pediatric subjects developed at the National School of Medicine from 1869 to 1905 (continued)

\begin{tabular}{|c|c|c|c|}
\hline Year & Author & Title & \\
\hline \multirow[t]{4}{*}{1898} & Nicolás Guerola & Purulent ophthalmia of newborns, bacteriology and treatment & $\stackrel{\infty}{-\infty}$ \\
\hline & Manuel Mestre Chigliazza & Brief notes on children enteritis & $\stackrel{\sim}{\sim}$ \\
\hline & Pedro M. Muro & Some considerations about whooping cough & $\gtrsim$ \\
\hline & Reynaldo Narro & Intestinal infection in the child & $\frac{\xi}{d 1}$ \\
\hline \multirow[t]{3}{*}{1899} & Mariano Zertuche & $\begin{array}{l}\text { Bottle-feeding, a study accompanied by analyses of different milks collected in barns, dair } \\
\text { and hospitals }\end{array}$ & y stor \\
\hline & Juan B. Amador & Study on childhood diarrheas and their treatment & $\check{\varpi}$ \\
\hline & Federico Martínez & Brief notes on early childhood hygiene & $\overline{\underline{n}}$ \\
\hline \multirow[t]{3}{*}{1900} & Enrique A. Castillo & Meningitis differential diagnosis in children & 르 \\
\hline & Bulmaro Flores & Brief notes on school-age diseases and their prophylaxis & $\subsetneq$ \\
\hline & Nicolás Guerola & Purulent ophthalmia of newborns, bacteriology and treatment & $\stackrel{\circ}{\frac{\rho}{f}}$ \\
\hline \multirow[t]{2}{*}{1901} & Samuel H. Salazar & Brief considerations about hereditary syphilis in Mexico &. $\bar{n}$ \\
\hline & Miguel M. Silva & Some considerations about children bronchopneumonia & $\frac{5}{d}$ \\
\hline \multirow[t]{2}{*}{1902} & Cristóforo Contreras & Some considerations about acute intestinal infection in early childhood & $\frac{\varsigma}{d}$ \\
\hline & Ricardo Villafuerte & Purulent ophthalmia prophylaxis & $\frac{7}{2}$ \\
\hline \multirow[t]{2}{*}{1903} & J. Trinidad Luna & School hygiene & 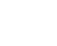 \\
\hline & Guadalupe Sánchez & Rickets & 일 \\
\hline \multirow[t]{2}{*}{1904} & Ramón E. Garduño & Treatment of children diarrhea clinical forms & 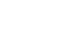 \\
\hline & Jesús Rodríguez Tovar & Children diseases that cause the highest mortality figure in Mexico & $\stackrel{0}{c}$ \\
\hline \multirow[t]{2}{*}{1905} & Lauro Camarillo & Some considerations about bottle-feeding & 3 \\
\hline & Eduardo Uribe & Brief considerations about purulent ophthalmia and its treatment & 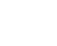 \\
\hline
\end{tabular}

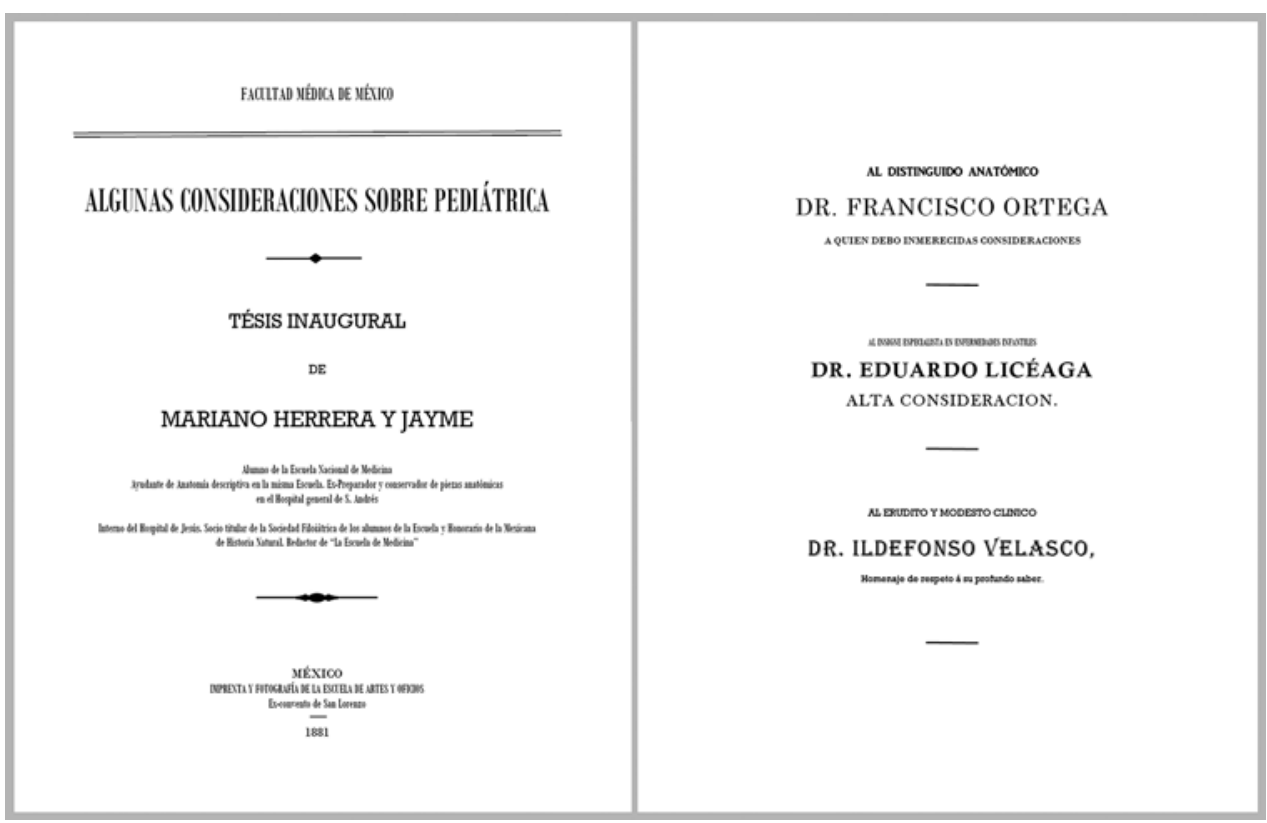

Figure 2. Cover of the inaugural thesis written by Mariano Herrera y Jayme, student of the National School of Medicine, 1881. 
"Chronic metritis. Dyspepsia. Symptomatic neurosis", and is dated on July 12, 1868; he published his last work when he was 75 years old, and it had the title "Importance of disseminating personal hygiene", dated on December 16, 1914. ${ }^{16,17}$

Dr. Liceaga's works confirm his interest and commitment to children's health and remind of his phrase: "I'm not in the children's department for the meager remuneration I receive, but to study childhood diseases."3 Almost all his observations were made in patients attending outpatient services or who were admitted to the Children's Hospital, where they received medical or surgical treatment. His first participation with a pediatric topic at the Academy was fortuitous: on the night of March 9, 1870, Dr. Lauro Jiménez had the floor granted since the previous session, but he reserved his reflections about the brain condition suffered by an aeronaut who had fallen from a hot-air balloon in the bull ring, waiting for the arrival of doctors Carmona and Reyes, with whom he has been discussing the diagnosis. This allowed Dr. Liceaga to talk about a 4 to 5-year-old girl affected with croup (laryngotracheobronchitis), whom he cured with ipecac syrup, which caused her frequent vomiting. ${ }^{18}$

The subsequent articles address surgical issues. The first one corresponds to a tracheostomy procedure compiled by Juan Cabral, a student of the School of Medicine. It was the case of a 10-month old boy who had suffered respiratory distress and cough for two months; under these circumstances, the mother had learned that Dr. Liceaga, a specialist in children's diseases, gave free consultation every day at the Maternity and Children's Hospital, and thus she brought her son. After examining him, Dr. Liceaga established the diagnosis of tracheal compression by two lymph node tumors. In view of the signs of imminent asphyxia, doctors Liceaga, Ortega and Casasola decided to perform a tracheotomy, for which the child was placed on a table in front of a window and Dr. Liceaga proceeded to perform the operation with care and ability, which lasted 10 minutes. However, owing to the previous suffocation, reactivating the boy's sensitivity was necessary with dynamic electricity on muscles and skin. Five days later, the tumors disappeared with the application of mercurial ointment and potassium iodide; the cannula was removed one month later. It is important pointing out three reflections of Dr. Liceaga:

1. Electricity is highly useful in cases of asphyxia and its use was established at the hospital for all children with that condition.
2. Tracheotomy is not that serious and should be practiced in conditions that can cause death.

3. It is not necessary for the cannula to be removed bit by bit.19

In general, the other surgical works refer to the treatment of bone and joint infections, probably because in those days their prevalence was high. Among his reports there is a sub-periosteal resection of the upper portion of the femur with bone regeneration in a 4-year old girl; the conclusions of the procedure indicate that the operation achieved bone regeneration and joint restoration, which was not lost thanks to the resection being performed with the sub-periosteal method. ${ }^{20}$ Another case refers to a 7-year old girl who was admitted to the Children's Hospital with suppurative arthritis in both elbows, left shoulder and tibiotarsal joint, as well as periostitis of the right tibia consecutive to smallpox. In that case, Dr. Liceaga highlighted the following:

1. The high frequency of arthritis secondary to smallpox.

2. That the treatment of periostitis with incisions and dressing with alcohol and cotton packaging prevents the spread of inflammation.

3. That severe arthritis can be managed with joint immobilization, anti-scrofulous treatment and good hygiene. ${ }^{21}$

In the Academy session of May 15, 1878, Dr. Liceaga presented the case of a 14-year old boy who had been operated two years prior at the Children's Hospital due to diffuse suppurative periostitis of the right tibia. The patient's medical history had been compiled by assistant José G. Buiza, and it referred that tibial resection had been performed in most part of its diaphysis, noting that regeneration was complete, that the bone was more voluminous, the scar was solid and movements could be executed, and thus the patient was considered to be completely healed.22,23

Another case he presented was that of a 17-year-old male patient with Pott vertebral disease, central osteitis of the dorsal vertebral bodies and a large abscess by congestion, who was surgically treated with carbolic alcohol washes and placement in a Bonnet device. ${ }^{24}$

Dr. Liceaga also published cases of vesical calculi operated with good success at the Children's Hospital. The first one was a 7-year old boy operated in collaboration with doctors Muñoz and Martínez del Bio; the patient had an irregular calculus of gray color that weighed 30 grams and measured $37 \times 33 \mathrm{~mm}$ removed. The second history corresponded to a 5-year 
old boy, who had an elliptical, rough, friable, similar to a strawberry but dirty-yellow in color calculus of $16 \times$ $13 \mathrm{~mm}$ removed. ${ }^{25}$ The last case was presented at the Academy session of June 8, 1881; it was about a 9-year old boy with a bladder stone, which was extracted without complications; the calculus, reddish in color, consisted of uric acid and urates. ${ }^{26}$

The remaining works refer to medical subjects; for example, a pseudohypertrophic spinal paralysis in a 9 -year old boy (attended to initially by Dr. Vicente Morales, who was in charge of the Second Department of the Children's Hospital), who improved physically and mentally thanks to the education he was given at the hospital and to the treatment: hydrotherapy, good nutrition, muscular faradization and strychnine. ${ }^{27}$

Dr. Liceaga also described a congenital anomaly; a 3-month old boy with the right auricle attached only at the level of the lobe. After an extensive medical literature review, doctor, Dr. Liceaga concluded that the deformity had not been described until that moment. ${ }^{28}$

One of his works, although included in Gaceta Surgical Therapeutics section, was actually a case of right dorsal scoliosis managed with medical treatment. It was about a 16-year old girl who was very tall, thin and pale, with lateral deviation of the spine, who was continuously maintained for 11 months in a Bonnet device, and subsequently allowed to stand up and kept upright by means of a perforated felt corset, made using a plaster cast with the same technique employed by Sayre in New York. The treatment benefits were notorious, and hence Dr. Liceaga concluded that no aggressive procedures or surgical operations were required for treatment, although he had not compared his approach with Calot's method and he hadn't made sure whether it entailed a real scientific advance. ${ }^{29}$

Dr. Liceaga's last work of is the comment on a book published in 1910 by Professors John W. Ritchie and Joseph S. Caldwell with the name Primer of Hygiene; Being a Simple Textbook on Personal Health and How to Keep it, which was translated, adapted and expanded by Dr. Manuel Uribe y Troncoso in 1913 with the name Cartilla de higiene personal. Dr. Liceaga mentions that although the work was aimed at school children, it also seemed destined to serve as a guide to teachers and mothers, who were to instill in children the first teachings on personal hygiene. He ends his work asking the Academy to grant its attention to the usefulness of advertising individual hygiene as the basis of public hygiene. ${ }^{17}$

A review of the publications allows observing that not all works are signed by doctor Liceaga, since he often relied on his assistants, such as Mr. Buiza or Mr. Cabral, for the preparation of patients' medical history and the description of therapeutic actions and patient evolution, which were orally presented in the weekly Academy sessions and later published in Gaceta, a procedure that supported the professional training of his assistants, just as it currently occurs with resident physicians.

\section{The opera magna: Hospital General}

Since 1881, the medical community had made the authorities of the country notice the convenience of building a general hospital that was adequate to the needs of the city. It took many years for this idea to become real. The 1888 annual presidential address mentioned that the Public Charity Lottery would give the government $\$ 600000.00$ pesos for the construction of a hospital; in the 1890 address, President Porfirio Díaz commented that the plans for the Hospital General were concluded and that its construction was to be initiated. It was until November 1895 when the Minister of the Interior, General Manuel González Cosío, commissioned Dr. Eduardo Liceaga and engineer Roberto Gayol Soto to develop the project for a hospital. In June 1896, Dr. Liceaga was appointed as medical director of the construction and engineer Gayol as general director of the project. ${ }^{30,31}$

The construction began on July 23, 1896 in a piece of land of $170776 \mathrm{~m}^{2}$, located at Colonia Hidalgo to the west of Calzada de la Piedad, donated by Mr. Pedro Serrano. In May of 1904, engineer Gayol left the technical direction of the project, with architect Manuel Robleda Guerra being left in charge, who concluded it on December 31 of same year. Since the beginning, the project considered the inclusion of two pavilions: one for children with non-infectious diseases and another destined to children with infectious diseases. These pavilions were to be distinguished from the others by floor-to-ceiling windows and were to be be surrounded by a corridor with rail, covered with a light roof, where children would be able to remain outdoors for most of part of the day. The school was to be located at short distance, where the patients whose illnesses allowed it would attend. The department of children with infectious diseases was to be be isolated by a wall, served by special staff for each group of diseases, the dishware would also be different for each group and each room would have a different dump for waste fluids and a special shutter to directly pass the clothes to the cart that would bring them to the disinfection stove. In 
addition, it was indicated that as soon as a room destined for isolation vacated, it was to be washed and disinfected and small-value objects infected by the patient were to be incinerated. ${ }^{32,33}$

On February 5, 1905, at 10 o'clock in the morning, President Porfirio Díaz, accompanied by his wife Doña. Carmelita Romero, vice president Ramón Corral, and all the ministers of state, opened Dr. Liceaga's dearest dream: to provide Mexico City with a worthy and fully equipped General Hospital.

The hospital began its activities the next day after the opening ceremony, when 216 patients were moved, 6 from the Maternity and Children's Hospital. With regard to children's medical care, Dr. Liceaga's program was met, as there were 55 beds intended for pediatric patients' hospitalization, 31 in Pavilion 23, where children with non-infectious pathology were cared for, predominantly surgical patients, in charge of Dr. Eduardo Vargas; and 24 in Pavilion 29, where care was provided to patients with infectious pathology, in charge of Dr. Manuel G. Izaguirre. The care of newborns remained in charge of Dr. Manuel Perea at Pavilion $24{ }^{31}$

The creation of the General Hospital led to the closure of San Andrés, González Echeverría and Maternity and Children's hospitals, with the latter becoming the Central Outpatient Clinic, where patients could request a bed or be treated for ailments that did not require hospitalization; in the case of children, small traumas, diathesic diseases at initial stages, conditions of the digestive system, among others, were looked after there. ${ }^{32}$

\section{The end}

Dr. Eduardo Liceaga y Torres, the most prominent personality of Mexican medicine, director of the National School of Medicine, chairman of the Higher Council of Health, honorary member and chairman on two occasions of the National Academy of Medicine, founder of the Conservatory of Music, responsible physician od the children's ward at San Andrés Hospital, first of its kind in the country, and first director of the Children's Hospital, passed away on January 14, 1920.

\section{References}

1. Kumate-Rodríguez J. Síntesis histórica: 1802-1994. En: Ávila-Cisneros I, Padrón-Puyou F, Frenk S, Rodríguez-Pinto M. Historia de la pediatría en México. México: Fondo de Cultura Económica; 1997.

2. Mendizábal G. Necrología. 1836-El Dr. Eduardo Liceaga ${ }^{\dagger 1920 . ~ ¡ A e t e r-~}$ num vale! Gac Med Mex. 1920;1:63-68.
3. Liceaga E. Mis recuerdos de otros tiempos. México: Talleres Gráficos de la Nación. 1949.

4. Peza JD. La beneficencia en México. México: Imprenta de Francisco Díaz de León; 1881.

5. Flores FA. Historia de la medicina en México desde la época de los indios hasta la presente. México: Oficina Tipográfica de la Secretaría de Fomento; 1888.

6. León N. La obstetricia en México. Notas bibliográficas, étnicas, históricas, documentarias y críticas de los orígenes históricos hasta el año de 1910. México: Tipográfica de la Vda. de F. Díaz de León, Sucesores; 1910.

7. Liceaga E. Exposición del descubrimiento del Dr. Koch y resultados obtenidos por los experimentadores que han empleado la linfa que usa ese profesor. Segunda parte. Inoculaciones de la linfa del Dr. Koch, en el hospital de niños. Gac Med Mex. 1891;26:121-133.

8. Vargas E. Sesión del 22 de enero de 1891. Acta número 16. Gac Med Mex. 1891;26:197-200

9. Castañeda-De-Infante C. Catálogo de tesis de medicina del siglo XIX México: Universidad Nacional Autónoma de México; 1988.

10. Rodríguez-De-Romo AC, Castañeda-De-Infante C. Catálogo de las tesis de medicina del siglo XX. México: Facultad de Medicina/Universidad Nacional Autónoma de México; 1999.

11. Herrera-Jayme M. Algunas consideraciones sobre pediátrica. [Tesis]. México: Facultad Médica de México; 1881.

12. Liceaga $\mathrm{E}$. Las inoculaciones preventivas de la rabia, estudio-leído en la Academia de Medicina de México, en las sesiones de los días 18 de abril, 2 y 30 de mayo y 6 de junio de este año. México: Imprenta de Ignacio Escalante. 1888.

13. Reyes A. Profilaxis de la rabia en México. Salubridad Pública. Documentos e informes presentados en la vigésima reunión anual de la Asociación Panamericana de la Salubridad Pública de 1892. EE. UU.: Republican Press Association; 1894.

14. Liceaga E. Las inoculaciones preventivas de la rabia. Rev Med Mex. 1888:1:229-237.

15. Pruneda A. Centenario del nacimiento del Dr. Eduardo Liceaga. Gac Med Mex. 1940:68-91.

16. Liceaga E. Metritis crónica. Dispepsia. Neurosis sintomáticas. Curación. Gac Med Mex. 1869:4:193-196.

17. Liceaga E. Importancia de divulgar la higiene personal. Gac Med Mex. 1915;10:344-347.

18. Domínguez M. Acta de la sesión del 9 de marzo de 1870. Gac Med Mex. 1870;5:84-88.

19. Cabral J. Cirugía práctica. Una observación de traqueotomía, recogida por el alumno de la Escuela de Medicina D. Juan Cabral. Gac Med Mex. 1871;6:120-124.

20. Liceaga E. Clínica externa. Resección sub-perióstica de la extremidad superior del fémur: curación; regeneración del hueso. Gac Med Mex. 1874;9:261-266.

21. Liceaga E. Cirugía práctica. Hospital de Infancia. Artritis supurada consecutiva a la viruela. Periostitis. Gac Med Mex. 1876:11:345-347.

22. Mejía D. Acta de la sesión del día 15 de mayo de 1878. Gac Med Mex. 1878;13:357-359.

23. Buisa JG. Cirugía. Periostitis difusa supurada; resección sub-perióstica. Regeneración. Curación. Gac Med Mex. 1878;13:361-368.

24. Liceaga E. Cirugía. Mal vertebral de Pott por osteítis central de los cuerpos de las vértebras dorsales. Absceso por congestión, de enormes dimensiones. Abertura amplia. Canalización. Curación. Gac Med Mex. 1878;13:351-357.

25. Liceaga E. Clínica quirúrgica. Hospital de Niños. Dos observaciones de cálculo vesical en los niños operados con buen éxito. Gac Med Mex. 1876;11:229-234.

26. Malanco F. Academia de Medicina. Sesión del 8 de junio de 1881. Acta No. 33 aprobada el 15 del mismo. Presidencia del Sr. Dr. Lucio. Gac Med Mex. 1881;16:298-299.

27. Liceaga E. Patología. Parálisis espinal seudo-hipertrófica. Gac Med Mex. 1884:19:470-475.

28. Liceaga E. Teratología. Despegamiento congénito del pabellón de la oreja derecha. Gac Med Mex. 1884;19:388-390.

29. Liceaga E. Terapéutica quirúrgica. Escoliosis dorsal derecha. Gac Med Mex, 1897:34:312-315.

30. XLVI Legislatura de la Cámara de Diputados, los presidentes de México ante la nación. Informes, manifiestos y documentos de 1821 a 1866. Tomo II: Informes y respuestas desde el 10 de abril de 1876 hasta el 4 de noviembre de 1911. México: Imprenta de la Cámara de Diputados; 1966.

31. Anzures-López B. Remembranzas del inicio de la pediatría en el Hospital General de México. Rev Med Hosp Gen Mex. 1999;62:5-10.

32. Liceaga E, Gayol R. Proyecto de Hospital General de la Ciudad de México. Memorias del Segundo Congreso Médico Panamericano. México: Hoeck y Compañía Impresores y Editores; 1898.

33. Liceaga E. El Hospital General de la Ciudad de México. Cronica Med Mex. 1903;6:96-129 